\title{
Aqueous electrophoretic deposition of YSZ electrolyte layers for solid oxide fuel cells
}

\author{
J. S. Cherng • J. R. Sau • C. C. Chung
}

Received: 3 July 2007 /Revised: 15 October 2007 / Accepted: 20 October 2007 / Published online: 23 November 2007

(C) The Author(s) 2007

\begin{abstract}
A 6- $\mu \mathrm{m}$-thick, dense, and uniform yttria-stabilized zirconia (YSZ) thin-film electrolyte for solid oxide fuel cell was able to be formed, via aqueous electrophoretic deposition, onto a porous Ni-YSZ cermet anode, which was made via attrition mill, pressure casting, and pressureless sintering. Nonconductive yet suitably porous substrates could be used for electrophoretic deposition, with the help of an auxiliary electrode. Ni/YSZ cermet presintered at $1,200{ }^{\circ} \mathrm{C}$ and reduced at $700{ }^{\circ} \mathrm{C}$, on the other hand, behaved like a metal electrode and required no more the use of such an auxiliary electrode. It was also found that the deposition rate increased with increasing current density and with decreasing $\mathrm{NH}_{4}$-polyacrylate concentration.
\end{abstract}

\section{Keywords Electrophoretic deposition $\cdot \mathrm{YSZ} \cdot \mathrm{SOFC}$}

\section{Introduction}

The most severe problem on the applications and developments of solid oxide fuel cell (SOFC) using $\mathrm{ZrO}_{2}$ as its electrolyte is its relatively high operating temperature $\left(\sim 1,000{ }^{\circ} \mathrm{C}\right)$, which is necessary to obtain sufficient ionic conductance [1]. This not only greatly restricts the selection

A contribution to ICMAT 2007, Symposium K.

J. S. Cherng $(\bowtie)$

Department of Materials Engineering,

Mingchi University of Technology,

84 Gungjuan Rd., Taishan,

Taipei 24301, Taiwan

e-mail: cherng@mail.mit.edu.tw

\section{J. R. Sau $\cdot$ C. C. Chung}

Department of Materials Science and Engineering,

National Dong Hwa University,

No. 1, Sec. 2, Da Hsueh Rd., Shoufeng,

Hualien, Taiwan 97401 of useable materials and their manufacturing processes but also causes such problems as electrode sintering, interfacial diffusion between the electrolyte and electrodes, and thermal stresses because of operation cycle. There are basically two approaches to solve this difficulty. One is to employ new electrolyte materials possessing higher ionic conductivity, such as $\mathrm{CeO}_{2}$ and $\mathrm{Bi}_{2} \mathrm{O}_{3}$ [2-4]. However, the redox behavior of the former and the insufficient strength and toughness of the latter remain to be solved before they can be practically utilized. The other approach, which is more practical, is to improve the manufacturing technique to obtain a thinner but gas-tight $\mathrm{ZrO}_{2}$ electrolyte film.

Various methods have been tested to make the $\mathrm{ZrO}_{2}$ electrolyte film, e.g., tape casting, colloidal casting, dry pressing, plasma spraying [5], electrochemical vapor deposition (EVD) [6], physical vapor deposition (PVD) [7], and more recently, electrophoretic deposition (EPD) [8]. Up to date, the most applicable SOFC system, which was developed by the Siemens Westinghouse Power, utilized EVD process for its $\mathrm{ZrO}_{2}$ electrolyte film. However, it is a very expensive process that prevents their achievements to be really commercialized. Because the cost of PVD is also high and most of the cheaper processes do have their difficulties of obtaining controllable precision and repeatable quality, EPD has become a prominent alternative with great potential.

EPD is a process with history. It employs a direct current (DC) electric field to move and deposit charged particles in suspension onto an arbitrarily shaped electrode with opposite charge. Such a process is ideal for ceramic materials, and even multilayer ceramic composites, with layer thickness down to $2 \mu \mathrm{m}$ [9], have been successfully made via EPD. This cheap and fast technique not only makes complicatedly shaped ceramic products possible for wide applications but also avoids such difficulties as debinder compared to other wet processes when additives are inevi- 
table. Most of all, the controllability of deposit thickness and uniformity, the simplicity of process apparatus, as well as the feasibility to mass production make EPD one of the best choices to fabricate the $\mathrm{ZrO}_{2}$ electrolyte film.

Numerous studies have been published on the use of EPD to produce ceramic films and coatings. Among them, some were devoted to the fabrication of the $\mathrm{ZrO}_{2}$ electrolyte film onto porous anode or cathode substrates [10]. In spite of both the economic and environmental disadvantages, however, most of these researches employed organic solvents, instead of water, as the carrier of their suspensions to avoid the detrimental effects of electrolysis of water on the quality of deposited film. Although there are a few studies [11-22] focused on the development of aqueous EPD technique with suppressed/controlled electrolysis problem, seldom has been found in the field of SOFC. In this paper, preparation of yttria-stabilized zirconia (YSZ) electrolyte film on a porous anode $\mathrm{Ni} / \mathrm{YSZ}$ cermet was investigated using aqueous EPD. In addition, the effects of process parameters on deposition rate and quality of the film were discussed.

\section{Experimental}

\section{$\mathrm{Ni} / \mathrm{YSZ}$ cermet}

NiO (NiO-F, INCO, Canada) and YSZ (HSY-3.0, Daiichi Kigenso, Japan) powders, with mean particle sizes of 0.3 and $0.5 \mu \mathrm{m}$, respectively, were mixed according to a $1: 1$ weight ratio and milled in distilled water $(\sigma \sim 0.5 \mu \mathrm{s} / \mathrm{cm})$ by using an attritor (Model 01, Union Process, USA). Suspensions with solid loading of $10 \mathrm{wt} \%$ were thus formed, and green cakes were subsequently made out of these slurries by pressure casting them through a $0.3-\mu \mathrm{m}$ filter (Versapor 800 , Pall, USA) using $\mathrm{N}_{2}$ gas at $15 \mathrm{~kg} / \mathrm{cm}^{2}$.

After drying at room temperature for $24 \mathrm{~h}$, thus-obtained cakes were presintered in air at various temperatures, ranging from 1,000 to $1,200{ }^{\circ} \mathrm{C}$, for $4 \mathrm{~h}$ to acquire suitable strength for subsequent handling and adequate porosity for both cosintering with the deposited films and future application as the anode of SOFC. Before EPD, some of the presintered cermet was heat treated at $700{ }^{\circ} \mathrm{C}$ for $1 \mathrm{~h}$ under flowing $\mathrm{Ar} / 10 \mathrm{vol} \% \mathrm{H}_{2}$ atmosphere to reduce $\mathrm{NiO}$ to $\mathrm{Ni}$. Micostructural observation was made by scanning electron microscopy (SEM, Hitachi S-2150, Japan), and phase identification was carried out by X-ray diffraction (XRD) using a Philips X'pert MPD equipment (The Netherlands).

\section{YSZ electrolyte}

YSZ suspensions (10 wt\%) to be employed in our EPD study were made by dispersing/deagglomerating the YSZ powder in distilled water with a shear mixer for 30 min and a high-energy ultrasound sonicator (XL2020, MISONIX, USA) for 10 min subsequently. To prevent the colloids from further agglomeration and easy sedimentation during EPD, various amounts of an anionic polyelectrolyte, namely,
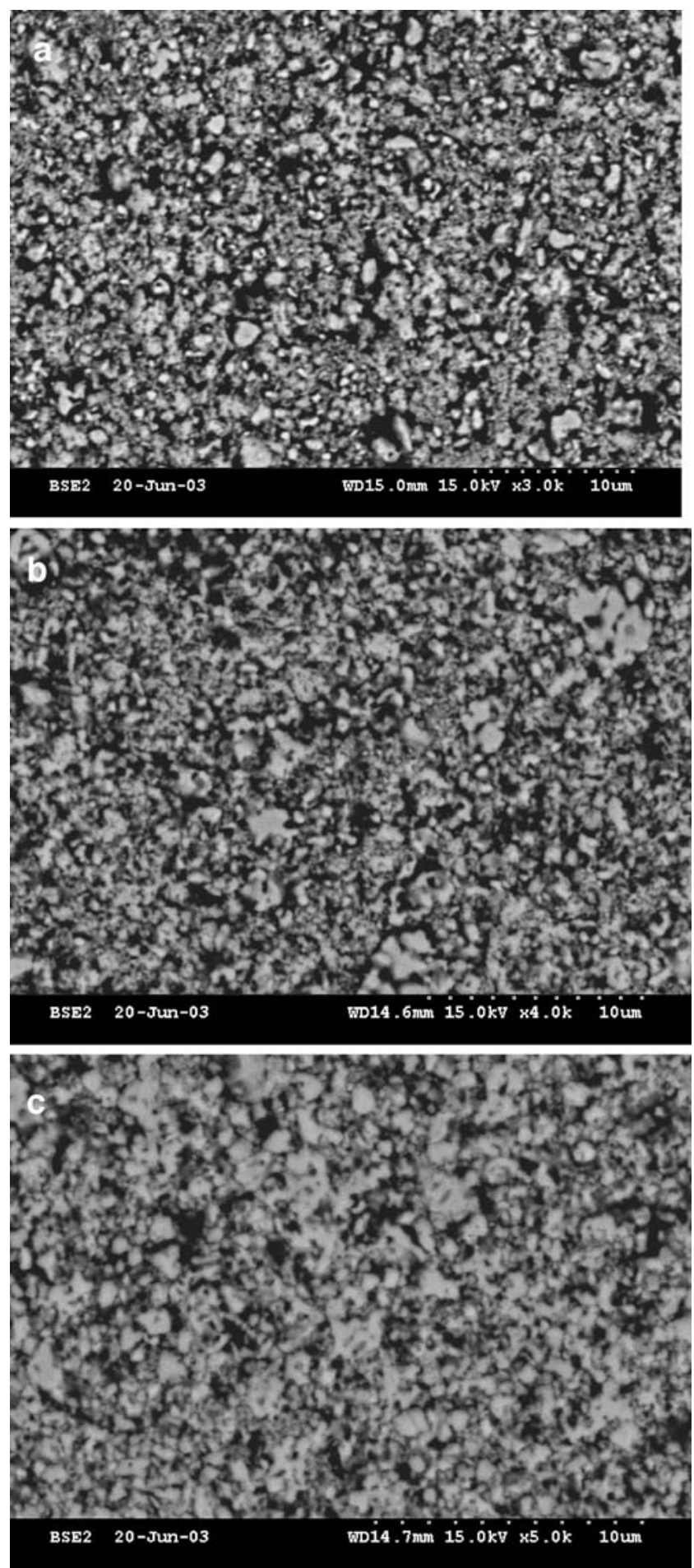

Fig. 1 Backscattered electron micrographs of Ni/YSZ cermets, after reduction treatment, which were presintered at a 1,000, b 1,100, and c $1,200{ }^{\circ} \mathrm{C}$, respectively 
ammonium polyacrylate (PAA-NH 4 , Darvan 821A, R.T. Vanderbilt, USA) were added as dispersant. PAA-NH would dissociate in water so that $\mathrm{PAA}^{-}$ions would adsorb to YSZ particles to stabilize them electrosterically.

Zeta potentials of these suspensions were determined by laser Doppler velocimetry (Zetasizer-3000HSA, Malvern, UK). The dilute samples required for these measurements were obtained from the upper parts of the suspensions after sedimentation eventually occurred. To evaluate the suspension stability, in addition to zeta potential measurement, the separation height, defined as shown in the inserts of Figs. $3 \mathrm{~b}$ and $4 \mathrm{~b}$, was also measured after the slurry was placed in still for $1 \mathrm{~h}$.

The EPD cell consisted of a Pt cathode and a Ni/YSZ cermet anode, with a copper plate tape-bounded to the back of the cermet as an auxiliary electrode, in an aforementioned suspension with suitable stirring. The distance between these two electrodes was $2 \mathrm{~cm}$. The deposition area was $2 \times 2.5 \mathrm{~cm}^{2}$. EPD was conducted under constant current control at various current densities. The voltage was registered during EPD. After drying, atmospheric cosintering of YSZ deposit and Ni/YSZ cermet substrate at $1,400{ }^{\circ} \mathrm{C}$ for $4 \mathrm{~h}$ followed. The microstructure was revealed by SEM.

\section{Results and discussion}

\section{$\mathrm{Ni} / Y S Z$ cermet}

Figure 1a,b, and c show the backscattered electron micrographs of Ni/YSZ cermets, after reduction treatment, which were presintered at $1,000,1,100$, and $1,200^{\circ} \mathrm{C}$, respectively.
Because the backscattering coefficient increases with increasing atomic number, the brightest phase should be $\mathrm{Ni}$, while the darker one YSZ, and the darkest one the pore. The uniformity of the microstructure is obvious throughout the samples while the porosity decreases with increasing presintering temperature, from $35 \%$ for the $1,000{ }^{\circ} \mathrm{C}$-sintered sample to $25 \%$ for the $1,200{ }^{\circ} \mathrm{C}$-sintered one according to quantitative stereography. This phenomenon results from higher diffusion rate at higher sintering temperature and is further demonstrated by the fact that the electric resistivity (two-point probe) decreases from $2.3 \times 10^{10} \Omega$-cm for the $1,100{ }^{\circ} \mathrm{C}$-sintered sample to $9.2 \sim 50 \times 10^{-2} \Omega$-cm for the $1,200{ }^{\circ} \mathrm{C}$-sintered one because of the more and more continuous $\mathrm{Ni}$ phase as shown in Fig. 1c. In addition, $\mathrm{XRD}$ analysis confirms that the reduction reaction has been completed so that all the diffraction peaks of $\mathrm{NiO}$ are replaced by that of $\mathrm{Ni}$, as shown in Fig. 2 .

\section{YSZ electrolyte}

Figure 3a shows that the zeta potential of aqueous YSZ suspension, without addition of $\mathrm{PAA}^{-\mathrm{NH}_{4}}$, varies continuously with the $\mathrm{pH}$ value, from about $40 \mathrm{mV}$ in acid to $-40 \mathrm{mV}$ in base. The colloidal stability is confirmed by the separation height measurement, as shown in Fig. 3b, which shows no separation at either very low or very high $\mathrm{pH}$ values but a maximum at about $\mathrm{pH} \mathrm{7,} \mathrm{the} \mathrm{isoelectric}$ point as shown in Fig. 3a. Nevertheless, it has been shown that aqueous EPD of such a YSZ suspension fails to deliver any dense and smooth deposit at either acidic or basic condition because of the electrolysis of water [23], despite the fact that it is stable at such extreme $\mathrm{pH}$ values.

With addition of PAA- $\mathrm{NH}_{4}$, however, it is found that both the enhancement of colloidal stability and the suppres-
Fig. 2 XRD patterns of $\mathrm{Ni} / \mathrm{YSZ}$ cermet, before and after $700{ }^{\circ} \mathrm{C}$ reduction

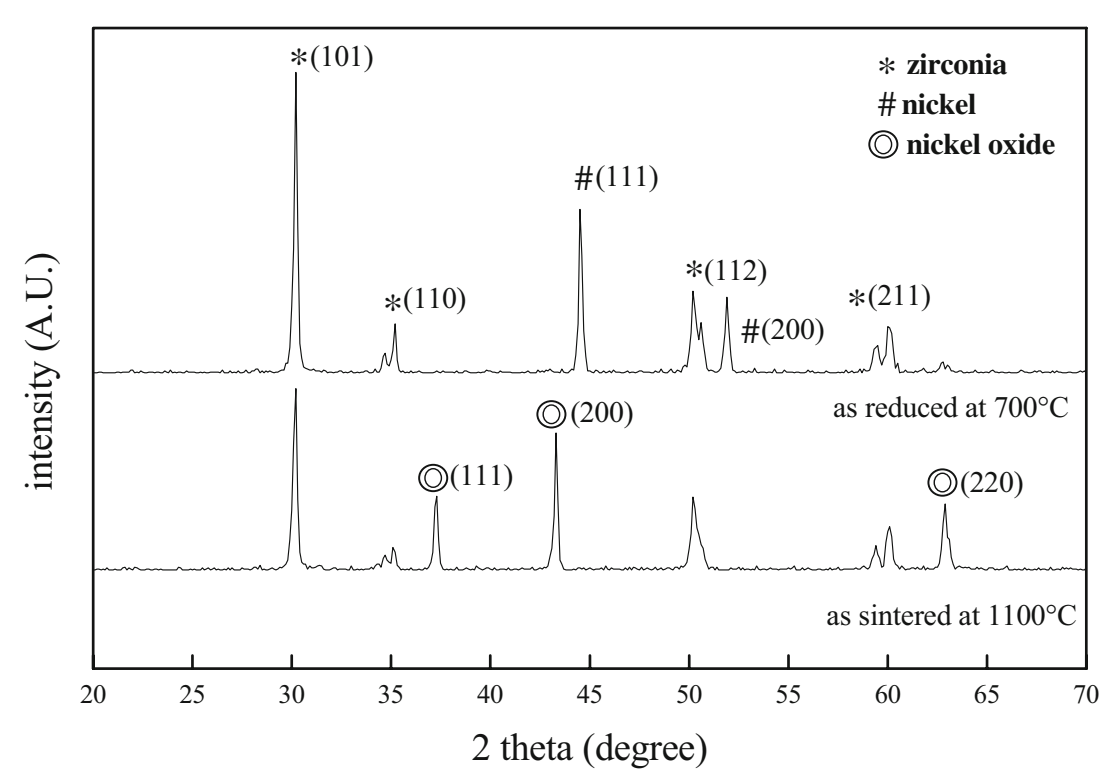


Fig. 3 Variations of a zeta potential and $\mathbf{b}$ separation height with $\mathrm{pH}$
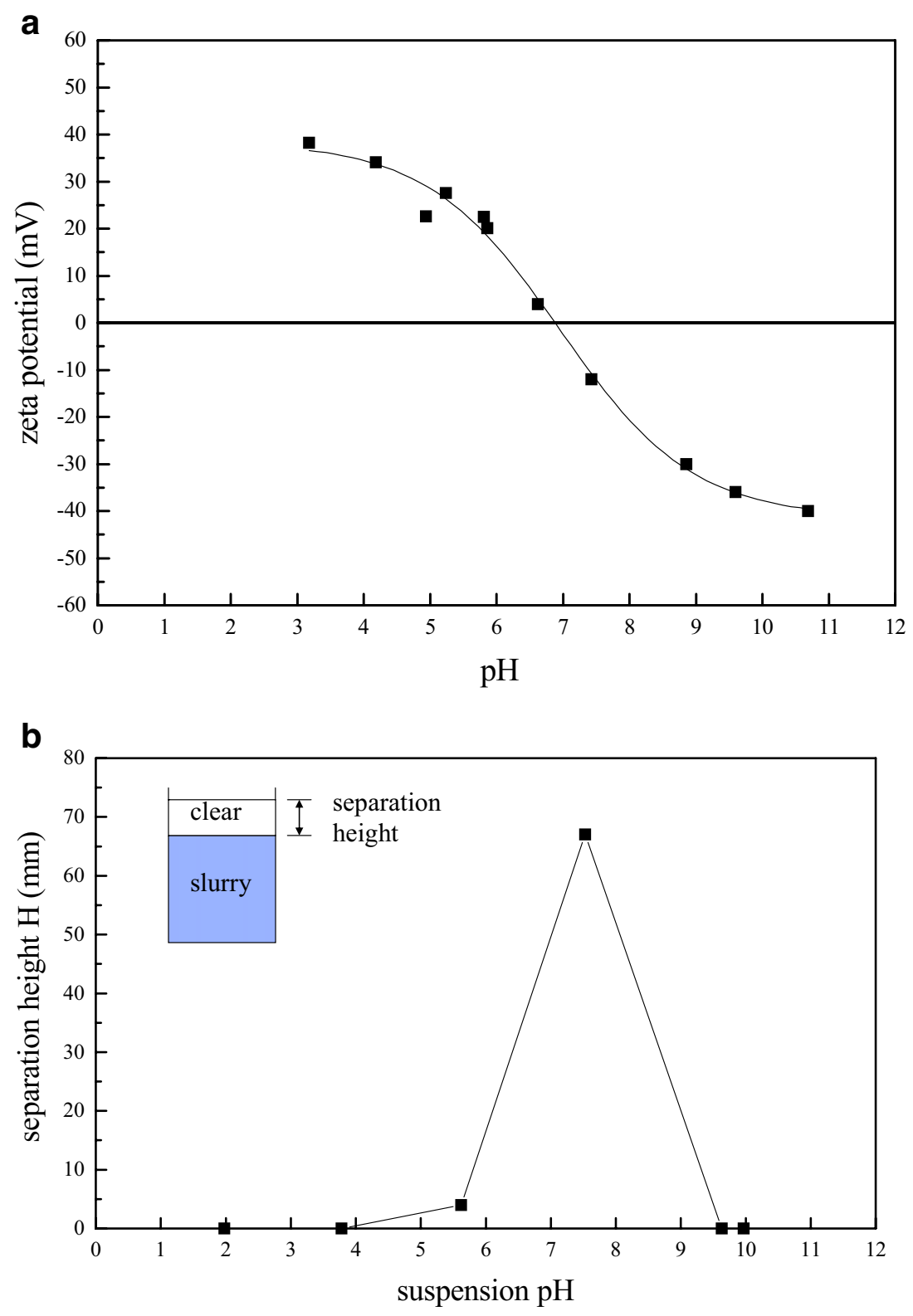

sion of water electrolysis can be achieved at the same time without any adjustment of $\mathrm{pH}$ value. Figure $4 \mathrm{a}$ demonstrates, although for only the electrostatic part, the variation of zeta potential with the addition of PAA-NH 4 . About $0.1 \mathrm{wt} \%$ of $\mathrm{PAA}^{-\mathrm{NH}_{4}}$ is enough to raise the zeta potential to $-40 \mathrm{mV}$ and stabilize the YSZ slurry. The measurement of separation height again confirms this point as shown in Fig. 4b. The added dispersant $\mathrm{PAA}-\mathrm{NH}_{4}$ dissociates into $\mathrm{PAA}^{-}$and $\mathrm{NH}_{4}^{+}$in water, with the former adsorbed onto the surface of YSZ particles so that the zeta potential becomes negative. The particles thus remain suspended eletrosterically and are able to move and deposit onto the cermet anode under a DC electric field. A typical result of our EPD experiments is shown in Fig. 5, where a white/opaque and dense YSZ film was formed on the porous green Ni/YSZ cermet after aqueous EPD and subsequent cosintering at $1,400{ }^{\circ} \mathrm{C}$ for $4 \mathrm{~h}$.

Figures 6 and 7 illustrate the effects of current density and dispersant concentration on deposition rate, respectively. It is found that the deposition rate increases with increasing current density and decreases with increasing PAA-NH ${ }_{4}$ concentration. The former is generally expected, while the latter can be rationalized as follows. With higher concentration of PAA- $\mathrm{NH}_{4}$ added and dissociated into $\mathrm{PAA}^{-}$and $\mathrm{NH}_{4}^{+}$in the suspension, the electric resistance of the suspension is found to become lower and so are the potential drop across the electrodes and the strength of electric field for EPD, under constant current control. This lowered driving force for electrophoresis thus lowers the deposition rate. Alternatively, one can also argue that with 
Fig. 4 Variations of a zeta potential and $\mathbf{b}$ separation height with the addition of PAA-NH
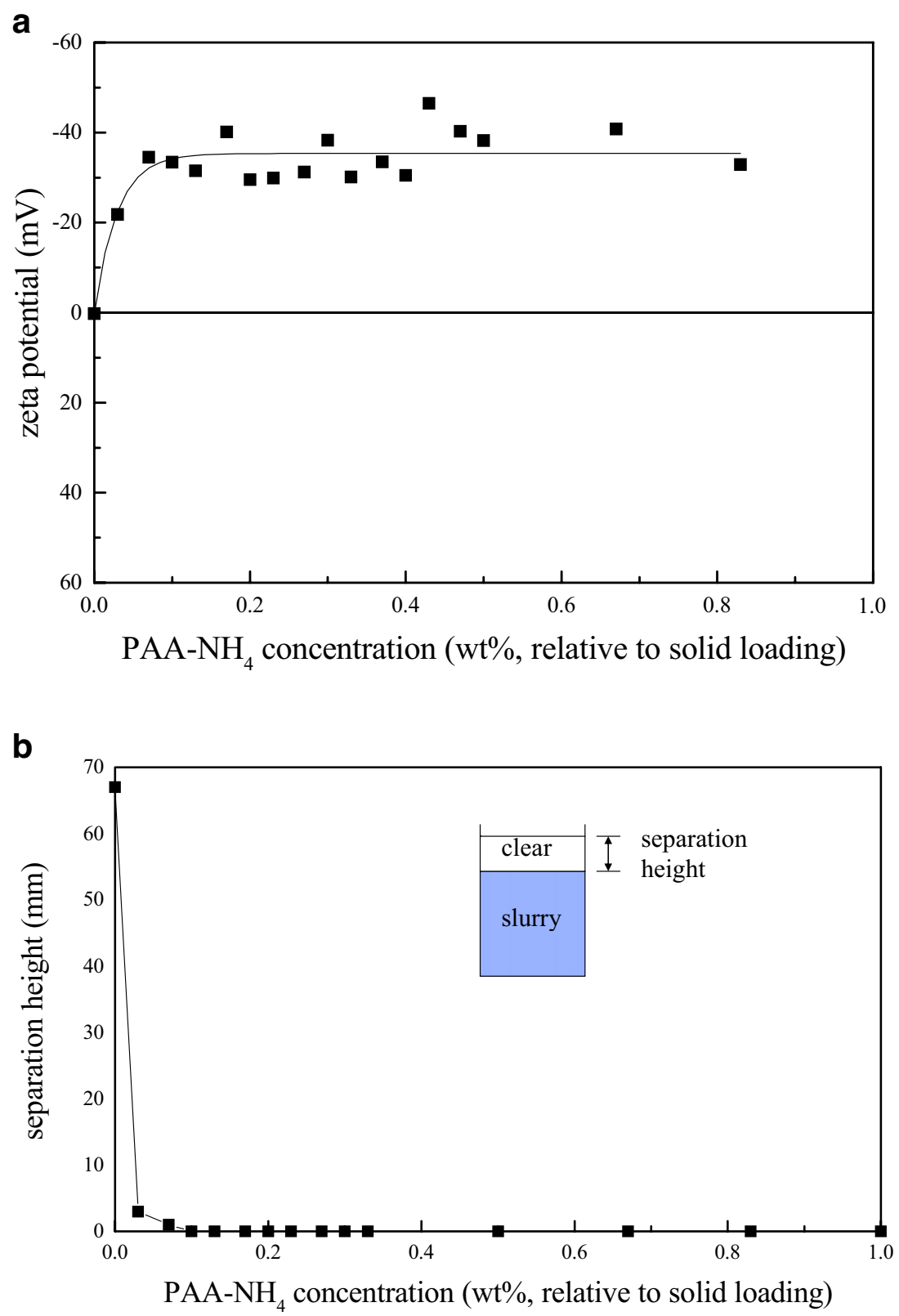

increasing PAA- $\mathrm{NH}_{4}$ concentration, the adsorbed amount of $\mathrm{PAA}^{-}$ions per YSZ particle becomes larger and thus dictates less amount of particles to be deposited on the anode because our EPD is proceeded at a constant current condition. Figure 8 schematically illustrates such a viewpoint of Faraday's law, where four particles on the left for the case of a low dispersant concentration carry the same amount of charge to be transferred as that carried by two particles on the right for the case of a high dispersant concentration. Therefore, lower dispersant concentration gives higher deposition rate. Further experiments and discussions to verify this argument will be presented in another paper to be followed soon.
Most of all, the uniformity and quality of the film can be controlled, from thicker to thinner films, as demonstrated by Figs. 9 and 10, which show scanning electron micrographs of the cross sections of two specimens, deposited at $2.2 \mathrm{~mA} / \mathrm{cm}^{2}$ for 75 and $30 \mathrm{~s}$, respectively, and sintered at $1,400{ }^{\circ} \mathrm{C}$ for $4 \mathrm{~h}$ subsequently. Dense and uniform YSZ films, about 15 and $6 \mu \mathrm{m}$ in thickness, respectively, are able to be made in this way. The highly uniform and dense microstructure of this YSZ film with grain size about $0.25 \mu \mathrm{m}$ is also shown in Fig. 11. Such a YSZ film guarantees gas tightness and effectively lowers the operation temperature of SOFC, especially when the film thickness becomes as low as $6 \mu \mathrm{m}$. Therefore, it is proven 


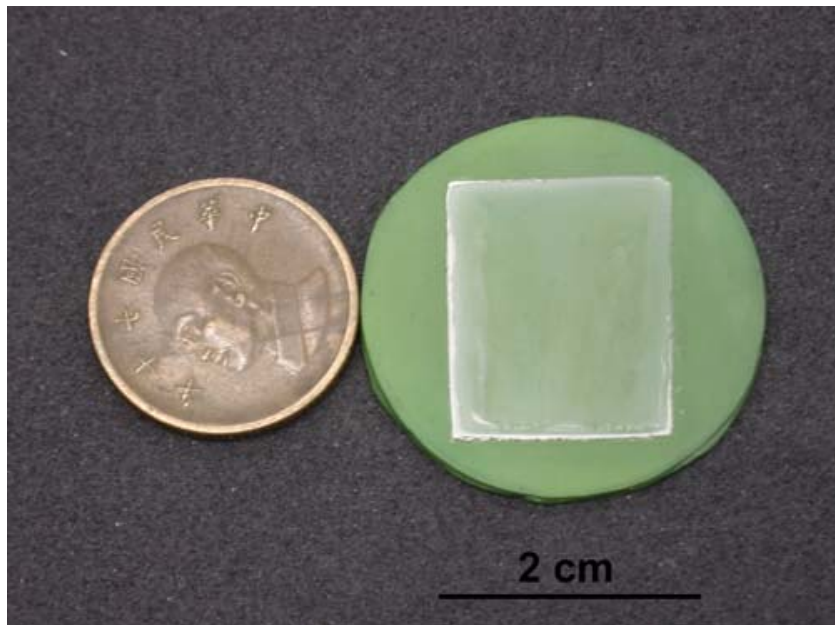

Fig. 5 A typical specimen cosintered at $1,400{ }^{\circ} \mathrm{C}$. The YSZ film (white/ opaque) was deposited on $\mathrm{Ni} / \mathrm{YSZ}$ cermet (green) via aqueous EPD

Fig. 6 Effects of current density on deposition rate

Fig. 7 Effects of PAA-NH concentration on deposition rate
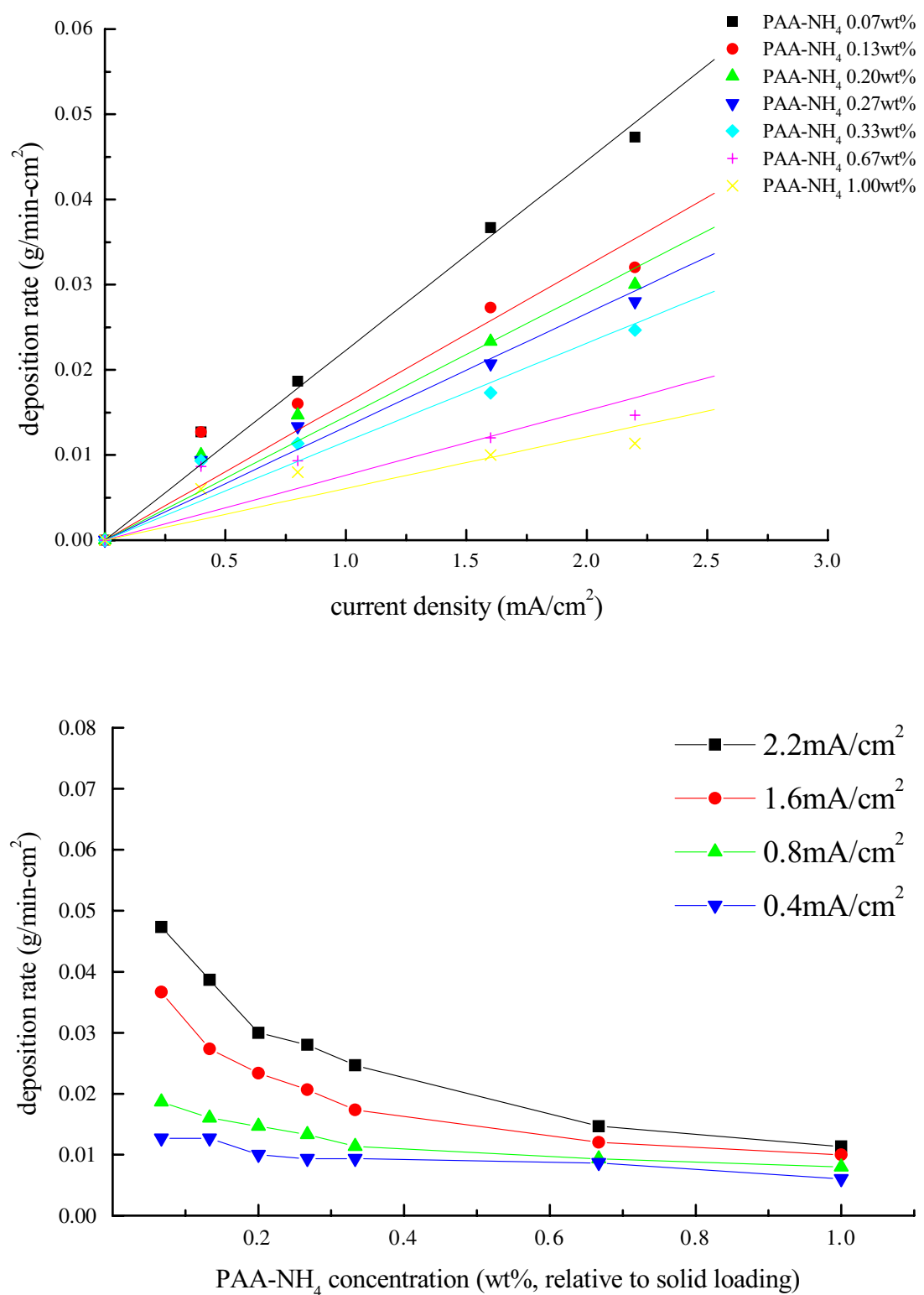

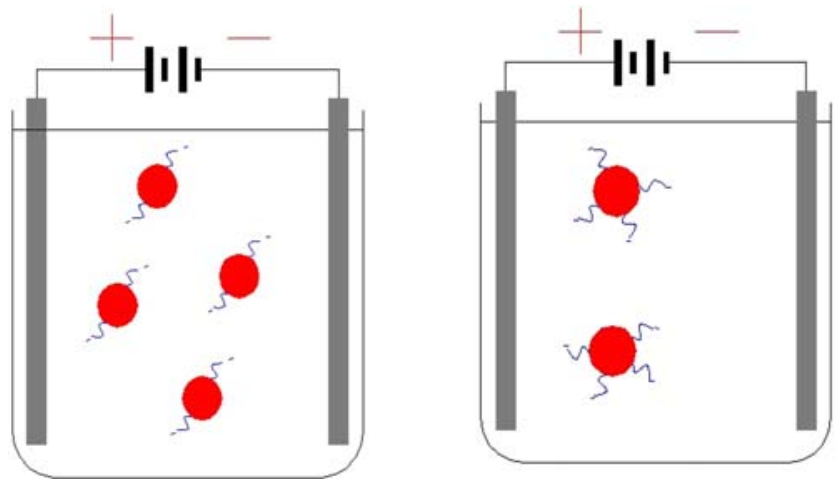

Fig. 8 A schematic illustrates the decrease of deposition rate with increasing adsorption of $\mathrm{PAA}^{-}$ions per YSZ particle, from the viewpoint of Faraday's law

that aqueous EPD is a powerful and versatile method to make a thin electrolyte film for SOFC applications.

Last but not least, there are some phenomena during EPD worth noting too. Figure $12 \mathrm{a}$ and $\mathrm{b}$ demonstrate typical results of voltage variation with time for EPD on $\mathrm{Ni} /$ YSZ cermets, which are presintered at $1,100{ }^{\circ} \mathrm{C}$, with and without reduction treatment, respectively. In general, there are two basic trends to be noted. Firstly, the voltage decreases with increasing PAA- $\mathrm{NH}_{4}$ concentration because of lower slurry resistance as mentioned before. Secondly, a comparison between these two figures elucidates the fact that the reduced substrate shows lower EPD voltage because of lower electrode resistance as expected. And above all, it is thus found that nonconductive yet suitably porous (i.e., containing effective through-pores) materials, like our Ni/YSZ cermets even without reduction treatment (i.e., $\mathrm{NiO} / \mathrm{YSZ}$, to be precise), could still be used as substrates for EPD, if only with the help of an auxiliary electrode. The seemingly irregular variations of voltage for all cermet substrates, especially for the ones with higher

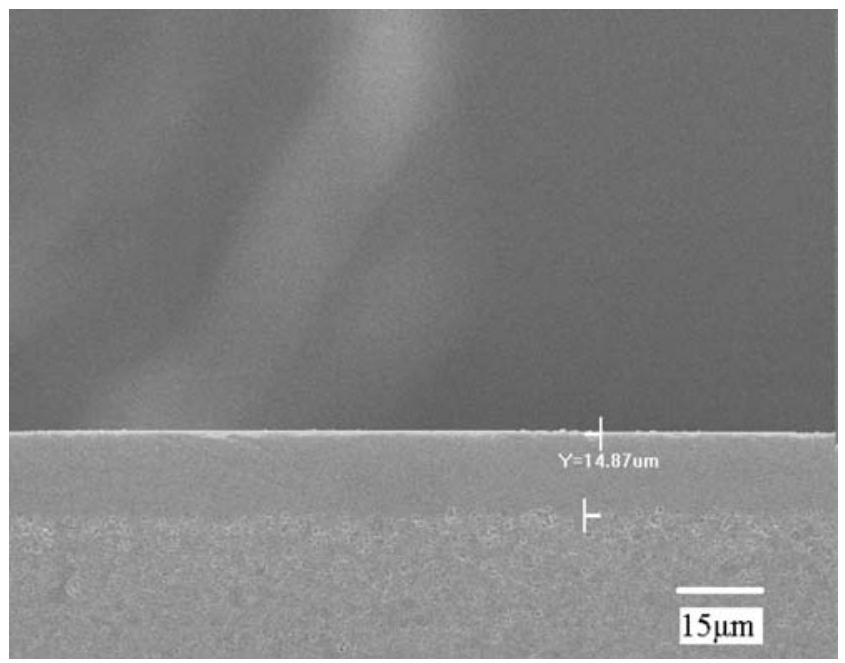

Fig. 9 Cross-section of a 15- $\mu \mathrm{m}$-thick YSZ film deposited at $2.2 \mathrm{~mA} / \mathrm{cm}^{2}$ for $75 \mathrm{~s}$, with $0.67 \mathrm{wt} \%$ of PAA- $\mathrm{NH}_{4}$, and sintered at $1,400{ }^{\circ} \mathrm{C}$ for $4 \mathrm{~h}$

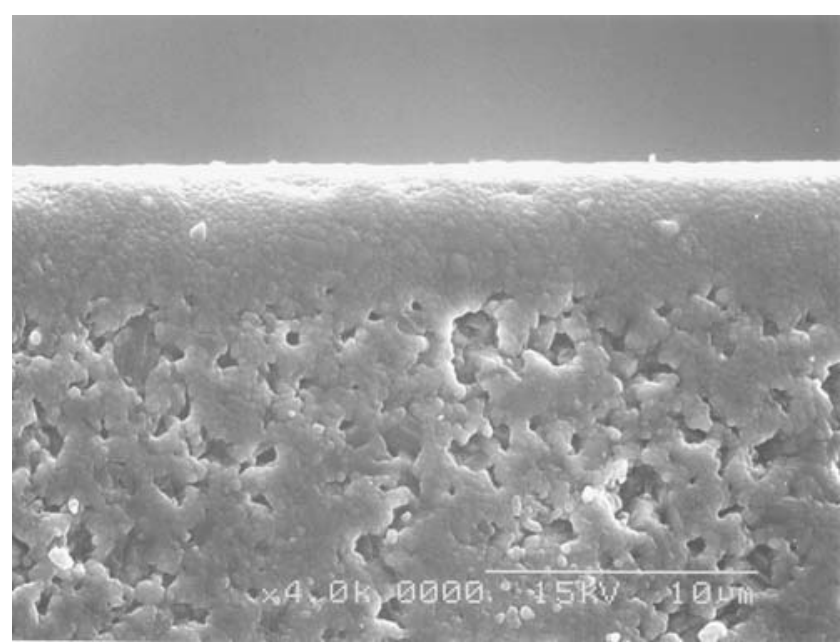

Fig. 10 Cross-section of a 6- $\mu$ m-thick YSZ film deposited at $2.2 \mathrm{~mA} / \mathrm{cm}^{2}$ for $30 \mathrm{~s}$, with $0.67 \mathrm{wt} \%$ of PAA- $\mathrm{NH}_{4}$, and sintered at $1,400{ }^{\circ} \mathrm{C}$ for $4 \mathrm{~h}$

voltage, simply correspond to the irregular variations of electrophoretic routes of the conductive species, either to or from the auxiliary electrode via the porous substrate and the growing porous deposit, during EPD. Thus, for instance, an increase in voltage during EPD might simply correspond to a just-developed blockage of electrophoretic routes of the conductive species.

When the presintering temperature is increased to $1,200{ }^{\circ} \mathrm{C}$, the unreduced substrate behaves similarly as shown in Fig. 13a, but the reduced cermet, exhibiting a certain $\mathrm{Ni}$ phase connectivity and electric conductivity as shown in Fig. 1c, behaves now just like a metal electrode where the voltage remains constant throughout the EPD experiments as shown in Fig. 13b. Also shown in Fig. 13b

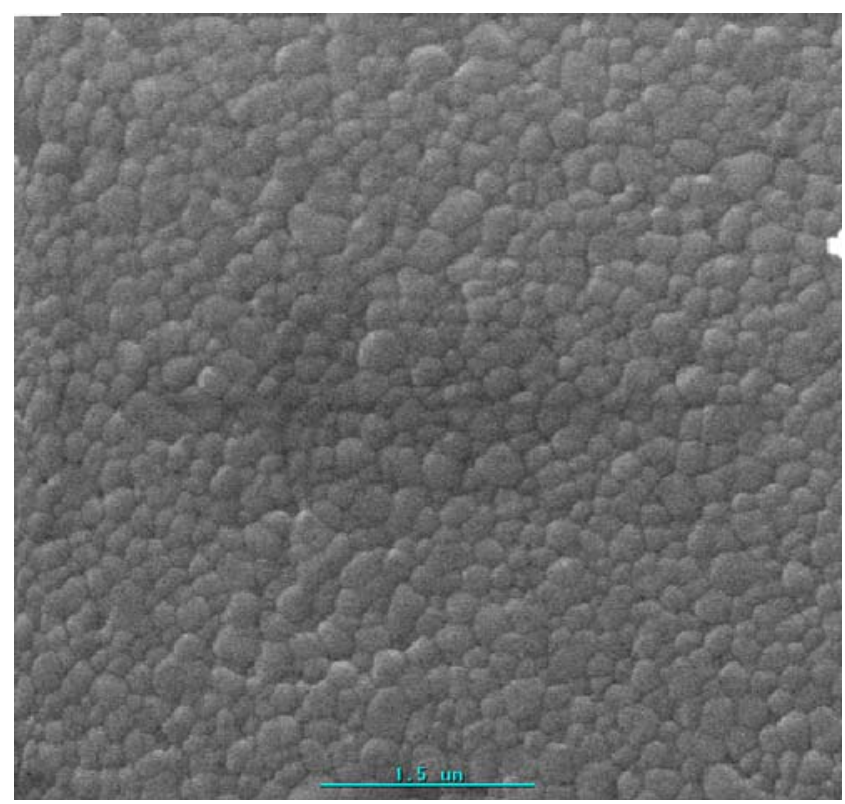

Fig. 11 Microstructure of a YSZ film deposited at $2.2 \mathrm{~mA} / \mathrm{cm}^{2}$ for $30 \mathrm{~s}$, with 0.67 wt. $\%$ of PAA- $\mathrm{NH}_{4}$, and sintered at $1,400{ }^{\circ} \mathrm{C}$ for $4 \mathrm{~h}$ 
a
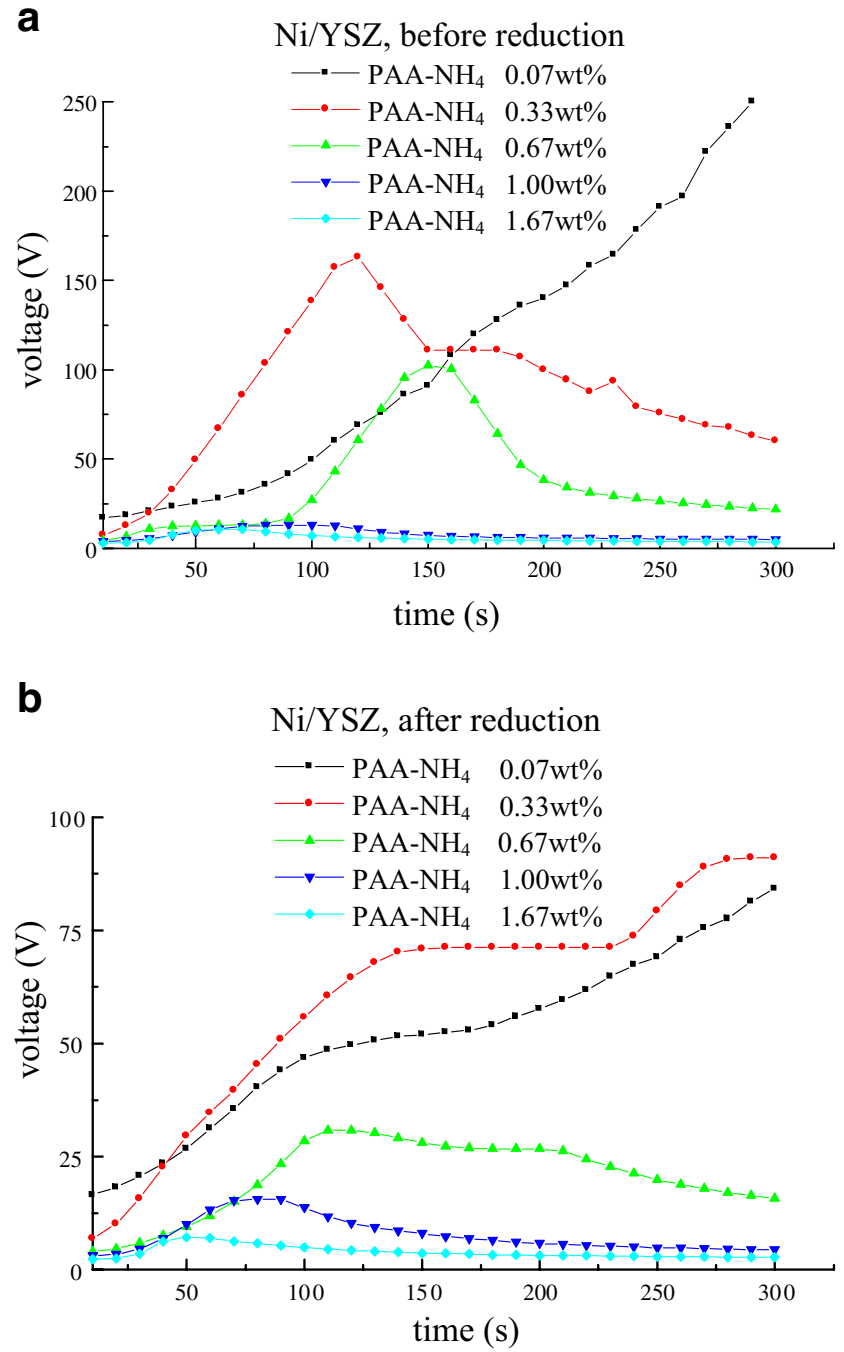

Fig. 12 Typical results of voltage measurement during EPD on $\mathrm{Ni} /$ YSZ cermets, presintered at $1,100^{\circ} \mathrm{C}$, a before and $\mathbf{b}$ after reduction treatment

are some data for $\mathrm{Zn}$ substrate. When comparing corresponding data in Fig. 13b for these two substrates, it is observed that $\mathrm{Zn}$ substrate shows lower voltages because it is more conductive than reduced Ni/YSZ.

It turns out that this $1,200{ }^{\circ} \mathrm{C}$-sintered and $700{ }^{\circ} \mathrm{C}$ reduced $\mathrm{Ni} / \mathrm{YSZ}$ cermet substrate requires no more the use of an auxiliary electrode. This fact is demonstrated by Fig. 14 where almost the same behavior as Fig. 13b is confirmed for this kind of substrate without the use of an auxiliary electrode.

\section{Conclusions}

A 6- $\mu \mathrm{m}$-thick, dense, and uniform YSZ electrolyte film on porous $\mathrm{Ni} / \mathrm{YSZ}$ cermet anode could be made via aqueous EPD and subsequent cosintering. Nonconductive but suitably porous materials could be used as substrates for EPD, a

$\mathrm{Ni} / Y S Z$, before reduction

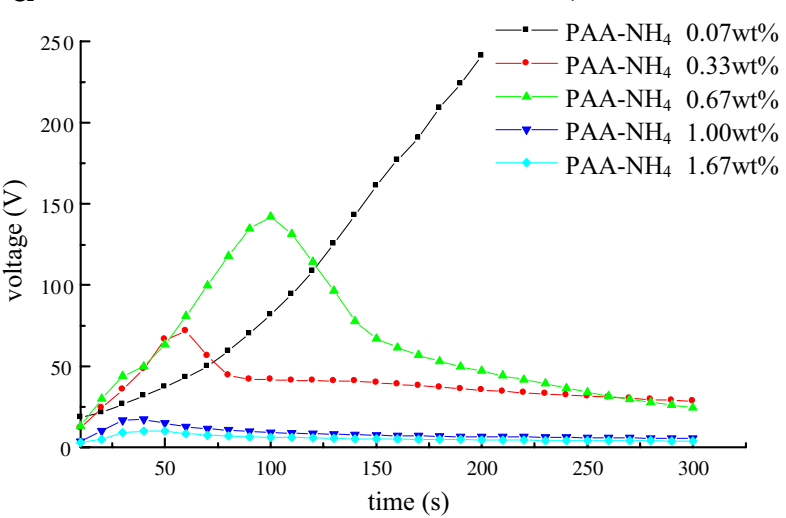

b $\mathrm{Ni} / \mathrm{YSZ}$, after reduction $\mathrm{Zn}$

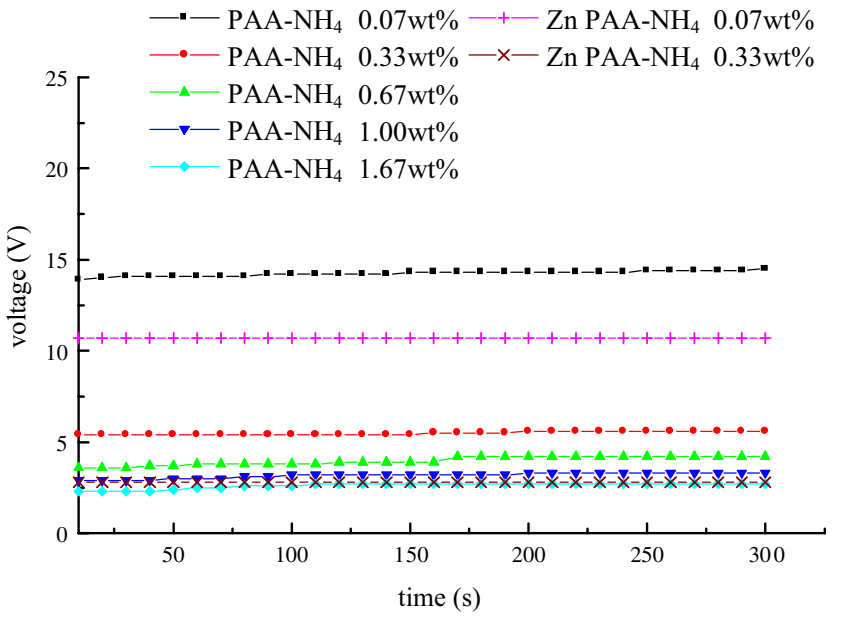

Fig. 13 Typical results of voltage measurement during EPD on $\mathrm{Ni}$ / YSZ cermets, presintered at $1,200{ }^{\circ} \mathrm{C}$, a before and $\mathbf{b}$ after reduction treatment. Some data for $\mathrm{Zn}$ substrate are also shown in $\mathbf{b}$

without auxiliary electrode

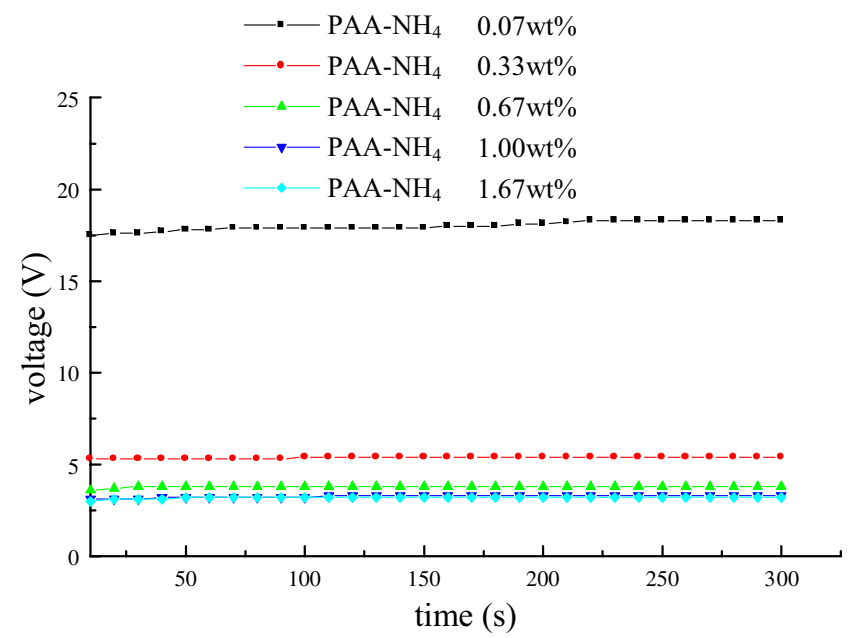

Fig. 14 Typical results of voltage measurement during EPD on $\mathrm{Ni} /$ YSZ cermets, presintered at $1,200{ }^{\circ} \mathrm{C}$ and reduction treated, without the use of an auxiliary electrode 
with the help of an auxiliary electrode. On the other hand, $\mathrm{Ni}$ / YSZ cermet presintered at $1,200{ }^{\circ} \mathrm{C}$ and reduced at $700{ }^{\circ} \mathrm{C}$ behaved like a metal electrode and required no more the use of an auxiliary electrode. It was also found that the deposition rate increased with increasing current density and with decreasing $\mathrm{PAA}-\mathrm{NH}_{4}$ concentration. A simple model based on Faraday's law could be used to explain the kinetics of EPD.

Open Access This article is distributed under the terms of the Creative Commons Attribution NonCommercial License which permits any noncommercial use, distribution, and reproduction in any medium, provided the original author(s) and source are credited.

\section{References}

1. Minh NQ, Takahashi T (1995) Science and technology of ceramic fuel cells. Elsevier, Amsterdam, The Netherlands, p 1

2. Steele BCH, Heinzel A (2001) Nature 414:345

3. Ishihara T, Honda M, Shibayama T, Minami H, Nishiguchi $H$, Takita Y (1998) J Electrochem Soc 145:3177

4. Zha S, Rauch W, Liu M (2004) Solid State Ion 166:241

5. Gruner HR, Tannenberger H (1994) First European solid oxide fuel cell forum. European SOFC Forum Secretariat, Lucerne, Switzerland, p 611
6. Sasaki H, Otoshi S, Suzuki M, Sogi T, Kajimura A, Sugiuara N, Ippomatsu M (1994) Solid State Ion 72:253

7. Honegger K, Batawi E, Sprecher C, Diethelm R (1997) Proceedings of SOFC V. Electrochemical Society, NJ, p 321

8. Sakar P, Nichoson PS (1996) J Am Ceram Soc 79:1987

9. Van der Biest O, Vandeperre LJ (1999) Annu Rev Mater Sci 29:327

10. Negeshi H, Sakai N, Yamaji K, Horita T, Yokokawa H (2000) J Electrochem Soc 147:1682

11. Garcia P, Ferrari B, Moreno R, Sanchez-Herencia AJ, Colomer MT (2007) J Eur Ceram Soc 27:4241

12. Moreno R, Ferrari B (2000) Mater Res Bull 35:887

13. Ferrari B, Moreno R (2000) J Electrochem Soc 147:2987

14. Ferrari B, Sanchez-Herencia AJ, Moreno R (1998) Mater Res Bull 33:487

15. Ferrari B, Moreno R (1997) J Eur Ceram Soc 17:549

16. Tang F, Sakka Y, Uchikoshi T (2003) Mater Res Bull 38:207

17. Tang F, Uchikoshi T, Ozawa K, Sakka Y (2003) Mater Res Bull 37:653

18. Tang F, Uchikoshi T, Sakka Y (2002) J Am Ceram Soc 85:2161

19. Uchikoshi T, Ozawa K, Hatton BD, Sakka Y (2001) J Mater Res 16:321

20. Thomas BJC, Boccaccini AR, Shaffer MSP (2005) J Am Ceram Soc 88:980

21. Tabellion J, Clasen R (2004) J Mater Sci 39:803

22. Nakahira A, Nishimura F, Kato S, Iwata M, Takeda S (2003) J Am Ceram Soc 86:1230

23. Chung CC (2002) M.S. thesis. National Dong Hwa Uviversity, Taiwan 